American Research Journal of Business and Management

(ARJBM)

ISSN (Online) : 2379-1047

Volume 2016, 7 pages

Research Article

Open Access

\title{
The E-Waste Management in the Public Sector: The Case of Bahrain
}

\author{
Marilou A. Maderazo, DBA ${ }^{1}$, Aaron Paul M. Pineda, DHRM ${ }^{2}$ \\ ${ }^{1}$ Higher College of Technology, Ras Al Khaima,United Arab Emirates \\ ${ }^{2}$ Middle East College, Knowledge Oasis Muscat, Muscat, Sultanate of Oman \\ aaronpaulpineda.app@gmail.com
}

\begin{abstract}
The researchers has conducted this study in order to analyze the preparedness of the e-waste management by the Bahrain Public Commission. The Bahrain Public Commission is a government organization which overlooks the protection of marine and environment in the Kingdom of Bahrain. All over Bahrain different colored boxes are kept for glass waste, paper waste and electronics waste. The same procedure is applied in the companies. The problem encountered is that not many people follow the waste management effectively. This may be due to lack of awareness which lead on recommendations for awareness program among the general public, hold training programs or awareness campaigns across the country.

The E-waste management system in the Kingdom of Bahrain is in its early stage of development it needs many steps toward the EMS in the developed countries and a strong bases for legislation enforcements. It was recommended that the region may develop an e-waste management system, a national framework for the management of e-waste, like awareness, education and involve the whole community, starting pilot plans on sorting and collection of electronic wastes, including take back plans and plans for repair recycling and refurbishment, provision of a strong regulatory environment.

Keywords: E-Waste Management, Bahrain Public Commission, E-Waste.
\end{abstract}

\section{INTRODUCTION}

E-waste in general is classified as hazardous waste in Bahrain as per the Ministerial Order No. 3 of 2006 with regards to the Hazardous Waste Management. Due to the nature, composition and toxicity of E-waste, it is being dealt as per the criteria and methodology mentioned in Basel Convention. The Kingdom of Bahrain is a signatory of the Convention and has ratified and implemented it in true spirit and form.

There exists no E-waste disposal or treatment facility in the kingdom of Bahrain, due to which the Environmental Regulatory Authority (Bahrain public Commission) favors its export to countries where such waste can be properly recycled and useful elements can be recovered in an environmental friendly manner. The main problem encountered in the country is lack of awareness in the management of E-waste due to which often it is being mixed with municipal and industrial waste and is being dumped at local landfill site. Such disposal cause irreversible harm to the soil, ground water and environmental resources. Thus, there is a great need for educating the people regarding E-waste segregation, proper storage, handling and disposal. On part of the Government, separate and dedicated E-waste disposal points are to be established where people can conveniently dispose their unwanted or used electronics and e-waste.

This study aimed in assessing the e-waste procedures adopted by the Public Commission in the Kingdom of Bahrain. Specifically this study sought to answer on the status and the level of effectiveness of the e-waste procedures adopted by the Public Commission in terms of Planning, Control, Storage, and Containment of Waste. 


\section{SYNTHESIS OF THE STUDY}

With regard to previous studies, this research study differs as it emphasizes and further handles the waste management strategic implementation in the company, especially the management. After reading the previous studies, the researcher has understood that most of the company departments develop their goals through formal documents like multi-year improvement plans, comprehensive plans, and task-force reports, the planning activities of their maintenance departments often are much less organized.

According to Ramachandran Rao (2008), Resource recovery and recycling from millions of tons of wastes produced from industrial activities is a continuing challenge for environmental engineers and researchers. This is true as for the Bahrain Public Commission it has become a big challenge for recovery and recycling of e-waste.

According to Joe Kausek (2008), in "Environmental Management Quick and Easy: Creating an Effective ISO 14001", The design and implementation of an ISO 14001 environmental management system (EMS) need not be complicated or costly, Materials producers are subject to all of the vagaries that confront any business, but have proven to be especially susceptible to demand and price variation due to their strong interdependency on (unpredictable) economic cycles and their position at the end of the supply chain.

Zerbock, (2008) Developed countries, however, still employ different methods of waste disposal (which largely depends on a country's policies and preferences). The large amount of solid waste (including its collection, transfer and disposal) generated in developed nations has been generally assumed by municipal governments

According to Montgomery (2008) Landfills can also be shifted to another use after their capacities have been reached. Bahrain doesn't have landmines, so this study is not useful for this research.

Salah Eddine (2008) There is no organized electronic waste management system in Morocco now. The case related to e-waste is automatically in concentration with, but not alarming tell moment. The Moroccan legal background, especially with Law 28-00, presents a suitable legal framework, also currently not sufficient.

few countries, controlling the main of their generated solid waste by using incinerators technique. Incineration, means controlled the burning of waste in a high temperatures to generate emission plus ash, is another waste disposal option and an alternative to landfilling (US Environmental Protection Agency, 2009).

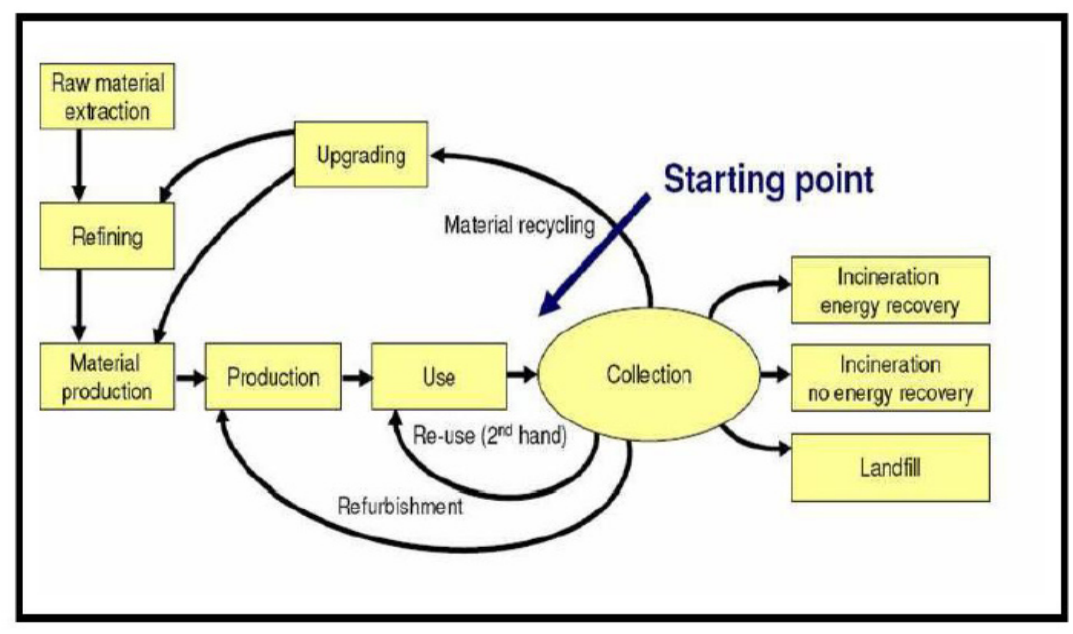

Figure1. $e$-waste management 
Theoretical framework of the study

Ref: Joe Kausek (2008), in "Environmental Management Quick and Easy: Creating an Effective ISO 14001"

The study was divided into two groups - A \& B with an average of 50 people selected in total from the Bahrain Public commission and the general public. Study of populations is almost always governed by the laws of probability, and the conclusions of the studies may thus not always be applicable to some individuals. This odd factor may be reduced by statistical means, but such a generalization may be too vague to imply anything.

\begin{tabular}{|c|c|c|}
\hline Respondents & Population N & Sample size \\
\hline Bahrain Public Commission & 50 & 20 \\
\hline General public & 50 & 30 \\
\hline TOTAL & $\mathbf{1 0 0}$ & $\mathbf{5 0}$ \\
\hline
\end{tabular}

Random sampling is a sampling technique where we select a group of subjects (a sample) for study from a larger group (a population). Each individual is chosen entirely by chance and each member of the population has a known, but possibly non-equal, chance of being included in the sample. By using random sampling, the likelihood of bias is reduced. There are many possibilities including: telephone surveys, paper and pencil surveys, web-based surveys, attitude surveys, observation of corrections jobs being performed, subject-matter-expert meetings, literature reviews, and field tests with experimental designs, trend analyses and projections.

The status of the e-waste procedures adopted by the Bahrain Public Commission in the Kingdom of Bahrain in terms of planning

\begin{tabular}{|c|c|c|c|c|}
\hline Planning & $\begin{array}{l}\text { Management } \\
\quad(\mathbf{N}=\mathbf{2 5})\end{array}$ & $\begin{array}{l}\text { public } \\
(\mathrm{N}=25)\end{array}$ & $\begin{array}{l}\text { Composit Mean } \\
(\mathbf{N}=\mathbf{5 0})\end{array}$ & $\begin{array}{l}\text { Qualitative } \\
\text { Description }\end{array}$ \\
\hline e-waste policy procedure in place & 2.12 & 1.48 & 1.80 & Disagree \\
\hline $\begin{array}{l}\text { The management under quality control to undertake } \\
\text { e-waste }\end{array}$ & 1.88 & 1.76 & 1.82 & Disagree \\
\hline Proper systematic procedures are in place & 1.84 & 2.16 & 2.00 & Disagree \\
\hline $\begin{array}{l}\text { Guidelines are provided to the management to carry } \\
\text { out e-waste }\end{array}$ & 3.24 & 2.56 & 2.90 & $\begin{array}{c}\text { Moderately } \\
\text { Agree }\end{array}$ \\
\hline Total & 2.27 & 1.99 & 2.13 & Disagree \\
\hline
\end{tabular}

The table shows the perceptions of the respondents on the status of the e-waste procedures adopted by the Public Commission in the Kingdom of Bahrain with a total mean of 2.13, i.e. they disagree. However, the respondents moderately agree that the guidelines are provided to the management to carry out e-waste with a weighted mean of 2.90 .

The status of the e-waste procedures adopted by the Bahrain Public Commission in the Kingdom of Bahrain in terms of control

\begin{tabular}{|c|c|c|c|c|}
\hline Control & $\begin{array}{l}\text { Management } \\
(\mathbf{N}=\mathbf{2 5})\end{array}$ & $\begin{array}{l}\text { public } \\
(\mathrm{N}=25)\end{array}$ & $\begin{array}{l}\text { Composite Mean } \\
(\mathbf{N}=\mathbf{5 0})\end{array}$ & $\begin{array}{l}\text { Qualitative } \\
\text { Description }\end{array}$ \\
\hline All e-waste are marked and categorized & 2.00 & 2.04 & 2.02 & Disagree \\
\hline All e-waste are placed in designated area & 3.68 & 4.04 & 3.86 & Agree \\
\hline Procedures are implemented accordingly & 3.08 & 3.44 & 3.26 & Agree \\
\hline $\begin{array}{l}\text { Number of e-waste on monthly \& yearly based } \\
\text { are noted }\end{array}$ & 3.76 & 2.44 & 3.10 & Agree \\
\hline $\begin{array}{ll} & \text { Total }\end{array}$ & 3.13 & 2.99 & 3.06 & Agree \\
\hline
\end{tabular}


The above table shows the perceptions of the respondents on the status of the e-waste procedures adopted by the Bahrain Public Commission in the Kingdom of Bahrain in terms of control with a weighted mean of 3.06, i.e. they agree. However not all e-waste are marked and categorized efficient with a mean on 2.02. Both the public commission management and the general public state that the e-waste is not convenient to the people.

The status of the e-waste procedures adopted by the Bahrain Public Commission in the Kingdom of Bahrain in terms of storage

\begin{tabular}{|l|c|c|c|c|}
\hline \multicolumn{1}{|c|}{ Storage } & $\begin{array}{c}\text { Management } \\
(\mathbf{N = 2 5})\end{array}$ & $\begin{array}{c}\text { Public } \\
(\mathbf{N = 2 5})\end{array}$ & $\begin{array}{c}\text { Composite Mean } \\
(\mathbf{N = 5 0 )}\end{array}$ & $\begin{array}{c}\text { Qualitative } \\
\text { Description }\end{array}$ \\
\hline e-waste are placed in designated area & $\mathbf{3 . 7 6}$ & $\mathbf{3 . 2 8}$ & $\mathbf{3 . 5 2}$ & Agree \\
\hline Safety procedures undertaken & 2.36 & 2.84 & 2.60 & $\begin{array}{c}\text { Moderately } \\
\text { Agree }\end{array}$ \\
\hline Residential or inhabited places not used & $\mathbf{2 . 2 4}$ & $\mathbf{2 . 4 8}$ & $\mathbf{2 . 3 6}$ & Disagree \\
\hline Storage area is properly secured & $\mathbf{2 . 7 2}$ & $\mathbf{3 . 2 8}$ & $\mathbf{3 . 0 0}$ & $\begin{array}{c}\text { Moderately } \\
\text { Agree }\end{array}$ \\
\hline \multicolumn{1}{r|}{ Total } & $\mathbf{2 . 7 7}$ & $\mathbf{2 . 9 7}$ & $\mathbf{2 . 8 7}$ & $\begin{array}{c}\text { Moderately } \\
\text { Agree }\end{array}$ \\
\hline
\end{tabular}

The table shows that the respondents moderately agree on the status of the e-waste procedures adopted by the Bahrain Public Commission in the Kingdom of Bahrain in terms of storage with a weighted mean of 2.87. This means that based on the respondents feedback, storage facility provided is efficient.

The status of the e-waste procedures adopted by the Bahrain Public Commission in the Kingdom of Bahrain in terms of containment of waste

\begin{tabular}{|l|c|c|c|c|}
\hline \multicolumn{1}{|c|}{ Containment of waste } & $\begin{array}{c}\text { Management } \\
(\mathbf{N = 2 5})\end{array}$ & $\begin{array}{c}\text { Public } \\
(\mathbf{N}=\mathbf{2 5})\end{array}$ & $\begin{array}{c}\text { Composite Mean } \\
(\mathbf{N = 5 0 )}\end{array}$ & $\begin{array}{c}\text { Qualitative } \\
\text { Description }\end{array}$ \\
\hline Storage area is properly secured & $\mathbf{2 . 9 2}$ & $\mathbf{2 . 8 8}$ & $\mathbf{2 . 9 0}$ & Moderately Agree \\
\hline $\begin{array}{l}\text { e-waste are stored away from public areas } \\
\text { and residential places }\end{array}$ & $\mathbf{1 . 8 8}$ & $\mathbf{1 . 6 8}$ & $\mathbf{1 . 7 8}$ & Disagree \\
\hline e-waste are not burnt & $\mathbf{2 . 0 4}$ & $\mathbf{2 . 0 4}$ & $\mathbf{2 . 0 4}$ & Disagree \\
\hline e-waste are dumped into the sea & $\mathbf{2 . 4 4}$ & $\mathbf{3 . 2 0}$ & $\mathbf{2 . 8 2}$ & Moderately Agree \\
\hline \multicolumn{1}{|r|}{ Total } & $\mathbf{2 . 3 2}$ & $\mathbf{2 . 4 5}$ & $\mathbf{2 . 3 8 5}$ & Disagree \\
\hline
\end{tabular}

The table shows the respondents disagree on the status of the e-waste procedures adopted by the Bahrain Public Commission in the Kingdom of Bahrain in terms of storage with a weighted mean of 2.385. It is likewise noted that the current e-waste are not burnt, with a mean of 2.04. The respondents also disagree that the e-waste are stored away from public areas and residential places.

The level of effectiveness of the e-waste procedures adopted by the Bahrain Public Commission in terms of planning

\begin{tabular}{|l|c|c|c|c|}
\hline \multicolumn{1}{|c|}{ Planning } & $\begin{array}{c}\text { Manage- } \\
\text { ment } \\
(\mathbf{N = 2 5})\end{array}$ & $\begin{array}{c}\text { Public } \\
(\mathbf{N}=\mathbf{2 5})\end{array}$ & $\begin{array}{c}\text { Composite } \\
\text { Mean } \\
(\mathbf{N}=\mathbf{5 0})\end{array}$ & $\begin{array}{c}\text { Qualitative } \\
\text { Description }\end{array}$ \\
\hline e-waste policy procedure in place & $\mathbf{1 . 8 4}$ & $\mathbf{1 . 8 4}$ & $\mathbf{1 . 8 4}$ & Least Effective \\
\hline $\begin{array}{l}\text { The management under quality control to undertake } \\
\text { e-waste }\end{array}$ & $\mathbf{1 . 2 8}$ & $\mathbf{1 . 6 8}$ & $\mathbf{1 . 4 8}$ & Least Effective \\
\hline
\end{tabular}


American Research Journal of Business and Management (ARJBM)

\begin{tabular}{|c|c|c|c|c|}
\hline Proper systematic procedures are in place & 1.56 & 1.56 & 1.56 & Least Effective \\
\hline $\begin{array}{l}\text { Guidelines are provided to the management to carry out } \\
\text { e-waste }\end{array}$ & 2.60 & 2.16 & 2.38 & Least Effective \\
\hline Total & 1.82 & 1.42 & 1.815 & Least Effective \\
\hline
\end{tabular}

The table shows the perceptions on the level of effectiveness of the e-waste procedures adopted by the Bahrain Public Commission in terms of planning, the respondents perceived these items to be least effective with a weighted mean of 1.815 .

Waste Management in Developed Countries - Brought basically by their more developed industries and more advanced technology, developed nations have more efficient and standard liquid waste management plans. According to Dan Madisson (2006) in "Process Mapping, Process Improvement and Process Management", states that the importance of process is in Process mapping and the key stakeholders' roles and responsibilities, the ten-step process redesign methodology, process improvement and creating the process team, the four lenses of analysis, customer report cards, benchmarking, and best practices

The level of effectiveness of the e-waste procedures adopted by the Bahrain Public Commission in terms of control

\begin{tabular}{|l|c|c|c|c|}
\hline \multicolumn{1}{|c|}{ Control } & $\begin{array}{c}\text { Management } \\
(\mathbf{N}=\mathbf{2 5})\end{array}$ & $\begin{array}{c}\text { Public } \\
(\mathbf{N = 2 5 )}\end{array}$ & $\begin{array}{c}\text { Composite Mean } \\
(\mathbf{N = 5 0 )}\end{array}$ & $\begin{array}{c}\text { Qualitative } \\
\text { Description }\end{array}$ \\
\hline All e-waste are marked and categorized & $\mathbf{2 . 2 4}$ & $\mathbf{1 . 6 0}$ & $\mathbf{1 . 9 2}$ & Least Effective \\
\hline All e-waste are placed in designated area & $\mathbf{4 . 9 6}$ & $\mathbf{4 . 5 2}$ & $\mathbf{4 . 7 4}$ & Highly Effective \\
\hline Procedures are implemented accordingly & $\mathbf{2 . 8 4}$ & $\mathbf{2 . 8 8}$ & $\mathbf{2 . 8 6}$ & $\begin{array}{c}\text { Moderately } \\
\text { Effective }\end{array}$ \\
\hline $\begin{array}{l}\text { Number of e-waste on monthly \& yearly } \\
\text { based are noted }\end{array}$ & $\mathbf{3 . 6 8}$ & $\mathbf{3 . 0 0}$ & $\mathbf{3 . 3 4}$ & $\begin{array}{c}\text { Moderately } \\
\text { Effective }\end{array}$ \\
\hline Total & $\mathbf{3 . 4 3}$ & $\mathbf{3 . 0 0}$ & $\mathbf{3 . 2 1 5}$ & $\begin{array}{c}\text { Moderately } \\
\text { Effective }\end{array}$ \\
\hline
\end{tabular}

The waste are marked and categorized was rated least effective with a mean of 1.92, however the efficiency and timely response to e-waste that are placed in designated area were rated highly effective with a weighted mean of 4.74. The next items were rated moderately effective with mean of 2.86 and 3.34

The level of effectiveness of the e-waste procedures adopted by the Bahrain Public Commission in terms of storage

\begin{tabular}{|l|c|c|c|c|}
\hline \multicolumn{1}{|c|}{ Storage } & $\begin{array}{c}\text { Management } \\
(\mathrm{N}=25)\end{array}$ & $\begin{array}{c}\text { Public } \\
(\mathrm{N}=25)\end{array}$ & $\begin{array}{c}\text { Composite Mean } \\
(\mathrm{N}=50)\end{array}$ & $\begin{array}{c}\text { Qualitative } \\
\text { Description }\end{array}$ \\
\hline e-waste are placed in designated area & 1.28 & 1.20 & 1.24 & $\begin{array}{c}\text { Very Least } \\
\text { Effective }\end{array}$ \\
\hline Safety procedures undertaken & 1.36 & 1.48 & 1.42 & $\begin{array}{c}\text { Very Least } \\
\text { Effective }\end{array}$ \\
\hline Residential or inhabited places not used & 1.88 & 2.04 & 1.96 & $\begin{array}{c}\text { Least } \\
\text { Effective }\end{array}$ \\
\hline Storage area is properly secured & 1.84 & 2.32 & $\mathbf{2 . 0 8}$ & $\begin{array}{c}\text { Least } \\
\text { Effective }\end{array}$ \\
\hline Total & 1.59 & 1.76 & 1.675 & $\begin{array}{c}\text { Least } \\
\text { Effective }\end{array}$ \\
\hline
\end{tabular}

Volume 2016 
The respondents consider the e-waste are placed in designated area as very least effective with a weighted means of $1.24 \& 1.42$. Residential or inhabited places not used are also considered least effective with a weighted mean of 1.96 and 2.08 .

The level of effectiveness of the e-waste procedures adopted by the Bahrain Public Commission in terms of containment of waste

\begin{tabular}{|l|c|c|c|c|}
\hline \multicolumn{1}{|c|}{ Containment of waste } & $\begin{array}{c}\text { management } \\
(\mathbf{N = 2 5})\end{array}$ & $\begin{array}{c}\text { public } \\
(\mathbf{N}=\mathbf{2 5})\end{array}$ & $\begin{array}{c}\text { Composite Mean } \\
(\mathbf{N}=\mathbf{5 0})\end{array}$ & Qualitative Description \\
\hline Storage area is properly secured & $\mathbf{3 . 3 6}$ & $\mathbf{2 . 9 2}$ & $\mathbf{3 . 1 4}$ & Moderate Effective \\
\hline $\begin{array}{l}\text { e-waste are stored away from pub- } \\
\text { lic areas and residential places }\end{array}$ & $\mathbf{2 . 7 2}$ & $\mathbf{2 . 8 4}$ & $\mathbf{2 . 7 8}$ & Moderate Effective \\
\hline e-waste are not burnt & $\mathbf{1 . 5 2}$ & $\mathbf{1 . 9 2}$ & $\mathbf{1 . 7 2}$ & Least Effective \\
\hline e-waste are dumped into the sea & $\mathbf{2 . 0 0}$ & $\mathbf{1 . 8 4}$ & $\mathbf{1 . 9 2}$ & Least effective \\
\hline Total & $\mathbf{2 . 4 0}$ & $\mathbf{2 . 3 8}$ & $\mathbf{2 . 3 9}$ & Least Effective \\
\hline
\end{tabular}

The table shows the perceptions of the respondents on the level of effectiveness of the e-waste procedures adopted by the Bahrain Public Commission in terms of containment of waste, the respondents perceived these items to be least effective with a weighted mean of 2.39. The respondents consider the dumping into the sea and that the e-waste process as least effective with a weighted means of $1.72 \& 1.92$.

The problems encountered by the respondents in the implementation of e-waste management in Bahrain Public Commission

\begin{tabular}{|c|c|c|c|c|}
\hline The problems encountered by the respondents & $\begin{array}{c}\text { Manage- } \\
\text { ment } \\
(\mathrm{N}=25)\end{array}$ & $\begin{array}{c}\text { Administra- } \\
\text { tors } \\
(\mathbf{N}=\mathbf{2 5})\end{array}$ & $\begin{array}{c}\text { Composite } \\
\text { Mean } \\
(\mathbf{N}=50)\end{array}$ & $\begin{array}{l}\text { Qualitative } \\
\text { Description }\end{array}$ \\
\hline e-waste policy procedure is not in place & 1.76 & 1.84 & 1.80 & Disagree \\
\hline The management doesn't undertake e-waste seriously & 1.52 & 1.68 & 1.60 & Disagree \\
\hline Proper systematic procedures are not followed & 1.76 & 1.56 & 1.66 & Disagree \\
\hline e-waste are not burnt & 2.40 & 2.16 & 2.28 & Disagree \\
\hline e-waste are dumped into the sea & 1.76 & 1.84 & 1.80 & Disagree \\
\hline Residential or inhabited places are used & 1.52 & 1.68 & 1.60 & Disagree \\
\hline Storage area is not secured from theft & 1.76 & 1.56 & 1.66 & Disagree \\
\hline All e-waste are unorganized & 2.40 & 2.16 & 2.28 & Disagree \\
\hline $\begin{array}{l}\text { Number of e-waste on monthly \& yearly based are } \\
\text { not recorded }\end{array}$ & 1.52 & 1.68 & 1.60 & Disagree \\
\hline Total & 1.86 & 1.81 & 1.808 & Disagree \\
\hline
\end{tabular}

The problems encountered by the respondents during the improvement of the e-waste management were mostly due to lack of procedures, seriousness, lack of systematic laws and lack of check. However from the survey both the respondents disagreed on these points with an average mean of 1.808

The failure to plan for such uncertainty leads to many forms of business woes including the inefficient use of capital, high inventory costs, missed sales opportunities, or poor customer responsiveness.

The E-waste management system in the Kingdom of Bahrain is in its early stage of development it needs many steps toward the EMS in the developed countries and a strong base for legislations enforcement. Some 
recommendations tips can be followed in the region for more improvement and development in e-waste management system. Create a national framework for the environmentally sound management of e-waste including wide public awareness and education and involve the whole community, Initiate pilot schemes on collection and sorting of e-wastes, including take back schemes and schemes for repair refurbishment and recycling provision of a strong regulatory environment - ban land fill and save the valuable resources away from land fill. Support E-waste collection programs, requiring retailers to accept cell phones for reuse, recycling or proper disposal. Pursue prepaid recycling fees, establish extended producer responsibility for electronics and centers for collection, temporary storage, dismantling and refurbishing. conduct awareness program on e-waste for school children and assist competent authorities to develop proper legislation for the management of E-wastes.

\section{REFERENCES}

[1] Bahrain Public Commission. Assessment Review 25 (5): 459-471. doi:10.1016/j.eiar.2005.04.007.

[2] Basel Action Network and Silicon Valley Toxics Coalition (2009). "Exporting Harm: The High-Tech Trashing of Asia" (PDF). Seattle and San Jose.

[3] Carroll (January 2008). "High-Tech Trash". National Geographic Magazine Online.

[4] Chea, Terence (2007). "America Ships Electronic Waste Overseas". Associated Press.

[5] Doctorow, Cory. "Illegal E-waste Dumped in Ghana Includes Unencrypted Hard Drives Full of US Security Secrets." Boing Boing. 25 June 2009. Web. 15 Mar. 2011.

[6] Grossman, Elizabeth (2006). "Where computers go to die - and kill Salon.com.

[7] Hicks, C.; Dietmara, R.; Eugsterb, M. (2008). "The Recycling and Disposal of Electrical and Electronic Waste in China-Legislative and Market Responses". Environmental Impact.

[8] Ingenthron, Robin (2011). "Why We Should Ship Our Electronic "waste" to China and Africa".

[9] Kahhat and Eric Williams, Center for Earth Systems Engineering and Management, Arizona State University, published Environmental Science and Technology June 2009.

[10] Kozlan, Melanie (2010). “What is 'E-Waste’ \& How Can I Get Rid Of It?!”. Four Green Steps.

[11] Ogunseitan, O.A.; Schoenung, J.M.; Saphores, J-D.M.; and Shapiro, A.A. (2009). “The Electronics Revolution: From E-Wonderland to E-Wasteland". Science 326: 670-671. doi:10.1126/science.1176929.

[12] Toxics Link (February 2009). "Scrapping the Hi-tech Myth: Computer waste in India”. India.

[13] Slade, Giles (2006). "Made To Break: Technology and Obsolescence in America”. Harvard University Press.

[14] William, AE, Product or Waste? Importation and End-of-Life Processing of Computers in Peru", Ramzy

[15] Yuan, C., Zhang, H. C., McKenna, G., Korzeniewski, C., and Li, J. “Experimental Studies on Cryogenic Recycling of Printed Circuit Board", International Journal of Advanced

[16] Manufacturing Technology, Vol. 34, 2007, pp. 657-666

Citation: Marilou A. Maderazo, DBA, Aaron Paul M. Pineda, DHRM, The E-Waste Management in the Public Sector: The Case of Bahrain. ARJBM Volume 2016; pp:1-7

Copyright (c) 2016 Marilou A. Maderazo, DBA, Aaron Paul M. Pineda, DHRM, This is an open access article distributed under the Creative Commons Attribution License, which permits unrestricted use, distribution, and reproduction in any medium, provided the original work is properly cited. 